Historic, Archive Document

Do not assume content reflects current scientific knowledge, policies, or practices. 


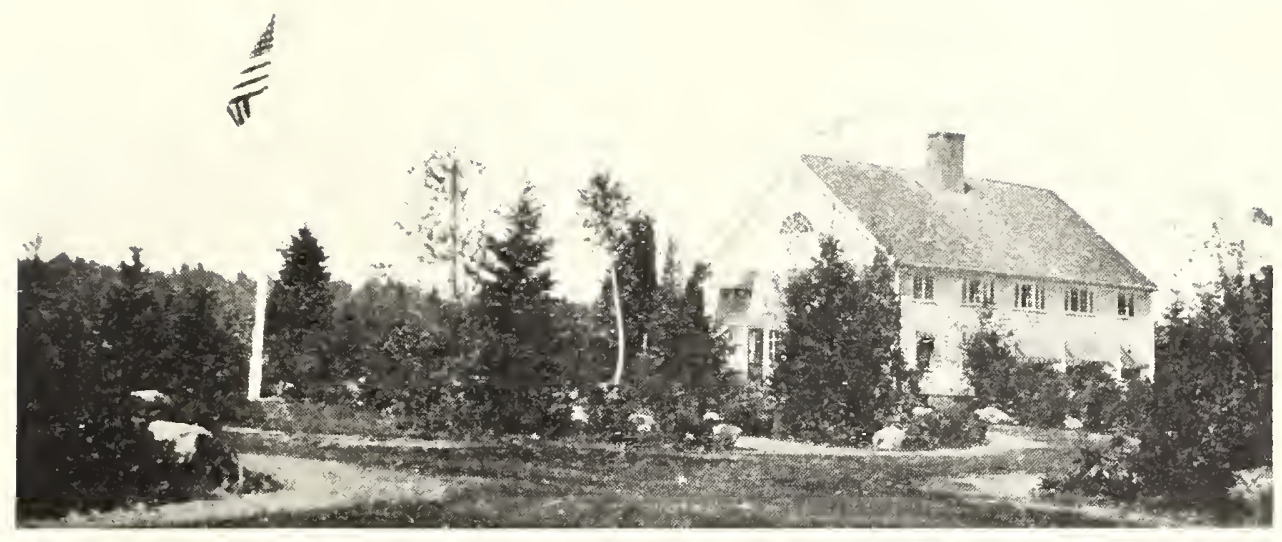

NEW OFFICE OF KELSEY-HIGHLANDS NURSERY, EAST BOXFORD, MASSACHUSETTS

\section{AUGUST AND SEPTEMBER ARE THE MOST SUCCESSFUL MONTHS FOR PLANTING SPECIMEN EVERGREENS, CONIFERS, RHODODENDRONS, KALMIAS, AND OTHER EVERGREENS.}

\section{WHEN AUGUST-SEPTEMBER COMES}

is the time for planting balled and burlapped specimen evergreens with greatest success.

WHY? It is the season of root growth. Conifers and Broadleaf Evergreens have usually finished their normal top growth by August 1st, and then begins root aitivity. Sap action has slowed down above ground, except for a ripening process and bud making, but is doing double time below the surface.

ALMOST A YEAR'S GROWTH MAY BE EARNED by August and September planting over waiting till Spring, for the root system becomes well established in the new location, and the proper physical contact with the soil insured; there is no check in growth the next season, as is often the case in Spring Planting, where it takes some time for the Transplant to "get ready" for growth. So August and early September have proved to be the best time for transplanting and establishing Specimen Evergreens, including the

\section{CONIFER GROUP}

Firs, Spruces, Hemlocks, Pines, Yews, Redcedars, Junipers, Arborvitaes and Cypress.

\section{BROADLEAF GROUP}

Rhododendrons, Kalmias, Leucothoe, Rose Daphne, Leiophyllum, Andromedas, Scotch Heather, Pachysandra, Vinca, Pachistima, etc.

VISIT KELSEY-HIGHLANDS NURSERY AT EAST BOXFORD, MASS., and see how we grow Specimen Trees and Shrubs. Good Automobile Roads from all directions; Salem, 13 miles; Boston, 28 miles; Lawrence, 9 miles; Ipswich, 6 miles; Manchester, 16 miles.

Always address

\section{HARLAN P. KELSEY, Owner EAST BOXFORD,}

Nursery Telefones, Topsfield 71 and 72.

MASSACHUSETTS. 


\section{AUGTST, SEPTEMBER AND IUTUMN PLANTING}

TIIE WILI) (IALDEN. The basis of all the best landscape work of a permanent nature must be Native l'lants, and particularly where naturalistic effects are desired. Erery garden or estate has its own peculiar problems, and a diseussion of details may prove helpful in unexpected ways. A Rock Garden (if wortly) is not simply a mass of rocks, some loam and a collection of alpine and dwarf plants! The artificial inust appear natural.

LILIES, TRILLIUMS AND OTIER PULBS. These may be planted from August to Norember. We grow them by thousands for use in Rhododendron plantings, and for gardens, borders and woodlands.

HARDY NATIVE AMERICAN PLANTS. The larest and best collections of Native Plants in existence. This has been a specialty for over 35 years, and there is Inardly a large estate or park in America that has not used stock from my Nurseries, either directly or indirectly, for the leading Nurseries are my customers.

\section{SPLCMEN RIIODODFNDRONS. KAIMIS, ANDROMEDAS AND AZALEAS FOR IMMEDIATE EFFECT}

THE HARDY YATVE IVERIC IN RHODODENDRONS are incomparably the best for general planting. It Kelsey-IIiohlands Nursery we have thousands of specimens ready for August, September and Fall planting. CAROLININUM, elear pink, CAROLINIANUM ALBLM, pure white or blush, CATAWBIENSE, bright resl-purple, and IAXIMUI, white, blooming in July, the latest of all.

RHODODENDRON IIYBRIDS. We have some of the best and hardiest varieties, as well as R. LAETIVIRENS. small clear-pink flowers in masses, and the MANCHURIAN, DAHURIAN, and KOREAN RIIODODENDIRONS.

MMERICAN HARDY AZALEAS. The finest Azaleas in the world for permanent planting under American conditions are the native deciduous species, including $\mathrm{A}$. arborescens, $\mathrm{A}$. vaseyi, A. calendulacea (Flame Azalea), A. nudiflora, A. viscosa, and A. canescens. AIso many Hardy Japanese and Asiatic Species.

KALMIA (Nountain Laurel), LEUCOTHOE, PIERIS FLORIBUNDA, LEIOPHYLLUMS (Mountain Heath), ELONYMUS, VINCAS, DAPHNE, GALAX, SIIORTIA, PACHYSANDRA, PACHISTIMA, and other broadleaf evergreens transplant perfectly in August and September. The beautiful ground cover ARCTOSTAPHYLOS or BEAR-BERRY, the new hardy dwarf KOREAN BOX and SCOTCH HEATHER in variety of color, we have in pot-grown plants.

\section{SPECHMEN CONIFERS-THE FIRS}

ABIES CONCOLOR, or White Fir, is perhaps the most strizing in appearance of our American Firs, with soft and dense silver foliage. ABIES FRASERI is a distinct species from the highest peaks of the Carolina mountains. It makes a perfect specimen lawn and screen tree, with dark green, thick-set foliage (blue underneath) and compact, pyramidal habit. ABIES HONOLEPIS, the Nikko Fir, and A. VEITCHI, Veiteh Fir, are two of the choicest and most striking of all the group as specimen lawn trees.

\section{THE JUNIPERS AND REDCEDARS}

JUNIPERUS VIRGINIANA, IEDCEDAR, is a specialty at Kelsey-Highlands Nursery, and specimens can be supplied up to 25 feet in height. There is no Evergreen more characteristic of our New England landscape, and for immediate and permanent effect nothing will take the place of the Redcedar. The varicty glauca has bright silver foliage, while var. keteleeri is a very compact pyramidal form.

THE PROSTRATE JUNIPER varies from the closely prostrate form to an erect type, 3 to 4 feet in height. It is the finest evergreen ground cover of our New England hills, and thrives in poorest sandy soils and exposed locations. O'THER FINE JUNIPERS are Pfitzer, Sargent, Irish, Swedish, Savin, Meyer, and Cannart.

\section{THE SPRUCES}

PICEA PUNGENS. Perhaps the best known is the famous PICEA l'UNGENS or Colorado Spruce, varying from the type which is bright green to the deep blue Koster variety. We have a fine list of others, including White, Alberta or Black Hills Spruce, Engelmann, Norway, Maxwell, Ycddo and Serbian Spruces, and the new and rare Picea koyamai and $P$. asperata.

\section{THE PINES}

A splendid stock of Pines, in specimen stock, from seedlings up to 16 feet, including White, Scotch and Austrian Pines, PINUS DENSIFLORA, CEMBRA, BANTSIANA, FLEXIIIS, JEFTREYI, IORAIENSIS, MONTANA, MONTICOLA, MUGHUS, NIGRA, PONDEROSA, RESINOSA, RIGIDA, THUNBERGI and others. Visit Kelsey-Highlands Nursery and see them-you will find it worth while.

\section{OTHER EVERGREENS}

PSEUDOTSUGA DOUglasi, Douglas Fir; TAXUS, Yews; 'THUJA, Arborritaes; CHAMAECYPARIS, etc., in many varieties, sizes and prices.

\section{THE HEMLOCKS}

TSUCA CAROLINIINA, the Carolina Ilemlock, is a grand new species, now universally accepted as the "Queen of American Evergreens." Introduced by Mr. Kelsey in 1884, it has become known to tree-lovers as the most distinctive and graceful of all conifers which are hardy throughout the entire United States. Thousands of perfect specimens up to 8 feet at Kelsey-Highlands Nursery.

TSUGA CANADENSIS, the Canada Hemlock, is one of our finest Native Conifers and used freely by all the best Landscape Architects.

\section{HARLAN P. KELSEY Kelsey-Highlands Nursery}

East Boxford,

$$
\text { "It's Not a Home until It's Planted" }
$$

